Atmos. Chem. Phys., 18, 11171-11183, 2018

https://doi.org/10.5194/acp-18-11171-2018

(C) Author(s) 2018. This work is distributed under

the Creative Commons Attribution 4.0 License.

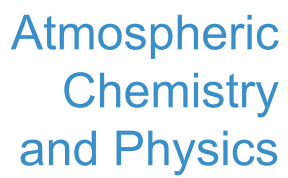

(c) (P)

\title{
Differentiating between particle formation and growth events in an urban environment
}

\author{
Buddhi Pushpawela, Rohan Jayaratne, and Lidia Morawska \\ International Laboratory for Air Quality and Health, Queensland University of Technology, GPO Box 2434, \\ Brisbane, QLD 4001, Australia
}

Correspondence: Lidia Morawska (1.morawska@qut.edu.au)

Received: 20 February 2018 - Discussion started: 13 April 2018

Revised: 11 July 2018 - Accepted: 20 July 2018 - Published: 10 August 2018

\begin{abstract}
Small aerosols at a given location in the atmosphere often originate in situ from new particle formation (NPF). However, they can also be produced and then transported from a distant location to the point of observation where they may continue to grow to larger sizes. This study was carried out in the subtropical urban environment of Brisbane, Australia, in order to assess the relative occurrence frequencies of NPF events and particle growth events with no NPF. We used a neutral cluster and air ion spectrometer (NAIS) to monitor particles and ions in the size range $2-42 \mathrm{~nm}$ on 485 days, and identified $236 \mathrm{NPF}$ events on 213 days. The majority of these events (37\%) occurred during the daylight hours with just $10 \%$ at night. However, the NAIS also showed particle growth with no NPF on many nights $(28 \%)$. Using a scanning mobility particle sizer (SMPS), we showed that particle growth continued at larger sizes and occurred on $70 \%$ of nights, typically under high relative humidities. Most particles in the air, especially near coastal locations, contain hygroscopic salts such as sodium chloride that may exhibit deliquescence when the relative humidity exceeds about $75 \%$. The growth rates of particles at night often exceeded the rates observed during NPF events. Although most of these night time growth events were preceded by day time NPF events, the latter was not a prerequisite for growth. We conclude that particle growth in the atmosphere can be easily misidentified as NPF, especially when they are monitored by an instrument that cannot detect them at the very small sizes.
\end{abstract}

\section{Introduction}

The formation of secondary particles in the atmosphere through homogeneous nucleation is known as new particle formation (NPF). This is one of the major sources of particles in the atmosphere. The condensable species that contribute are mainly sulfuric acid and semivolatile organic compounds and the process is thought to occur by binary watersulfuric-acid or ternary water-sulfuric-acid-ammonia nucleation. Particles, thus formed, form stable clusters that continue to grow to larger sized particles by vapour condensation or by coagulation with other particles (Kulmala et al., 2013).

The particle formation rate and the particle growth rate are the two most important parameters used to characterise an NPF event. The particle formation rate is the rate of formation of smallest measurable size of the particles, generally in the size range $2-3 \mathrm{~nm}$. This is different to the actual nucleation rate (the rate at which the stable clusters form). The particle growth rate varies with particle size (Manninen et al., 2010; Gagné et al., 2011; Backman et al., 2012) and, hence, the reported values depend on the detectable size ranges of the instruments used. Until recently, studies have been limited to measure the particles above $3 \mathrm{~nm}$. However, it is only during the past decade that the advancement of instruments has developed to such a level that particles of $2 \mathrm{~nm}$ or even smaller can be measured (Kulmala et al., 2012).

NPF has been observed under a range of environmental conditions, on every continent in the world (Kulmala et al., 2004; Backman et al., 2012; Gagné et al., 2011; Manninen et al., 2009, 2010; Rose et al., 2015; Pushpawela et al., 2018; Jayaratne et al., 2017). The occurrence rate of NPF is mainly dependent on the nature and concentration of gaseous precursors, which are controlled by a number of factors including 
Table 1. Summary of studies reporting night time NPF events: scanning mobility particle sizer (SMPS), air ion spectrometer (AIS), balanced scanning mobility analyser (BSMA), fast mobility particle sizer (FMPS).

\begin{tabular}{|c|c|c|c|c|}
\hline \multirow[b]{2}{*}{ Study } & \multirow[b]{2}{*}{ Location } & \multicolumn{2}{|c|}{ Occurrence rate } & \multirow[b]{2}{*}{$\begin{array}{l}\text { Instrument (size } \\
\text { range) }\end{array}$} \\
\hline & & Day time & Night time & \\
\hline $\begin{array}{l}\text { Svenningsson } \\
\text { et al. (2008) }\end{array}$ & $\begin{array}{l}\text { Abisko, Sweden } \\
\text { (characterised by subartic } \\
\text { birch forest) }\end{array}$ & $46 / 195$ days ( $23 \%)$ & $\begin{array}{l}31 / 195 \text { days } \\
(16 \%)\end{array}$ & $\begin{array}{l}\text { SMPS }(10-500 \mathrm{~nm}) \\
\text { AIS }(0.4-40 \mathrm{~nm})\end{array}$ \\
\hline Junninen et al. (2008) & $\begin{array}{l}\text { Pine Forest, Hyytiala, } \\
\text { Finland }\end{array}$ & & $344 / 1279$ days $(27 \%)$ & $\begin{array}{l}\text { BSMA }(0.4-6.3 \mathrm{~nm}) \\
\text { AIS }(0.34-40 \mathrm{~nm})\end{array}$ \\
\hline Suni et al. (2008) & $\begin{array}{l}\text { Eucalypt forest, } \\
\text { Tumbarumba, Australia }\end{array}$ & $184 / 351$ days $(52 \%)$ & $\begin{array}{l}\text { 112/351 days } \\
(32 \%)\end{array}$ & AIS $(0.34-40 \mathrm{~nm})$ \\
\hline Kalivitis et al. (2012) & $\begin{array}{l}\text { Finokalia, Lassithiou, } \\
\text { Greece (remote coastal } \\
\text { site) }\end{array}$ & $\begin{array}{l}53 / 365 \text { days } \\
(15 \%)\end{array}$ & $\begin{array}{l}39 / 365 \text { days } \\
(11 \%)\end{array}$ & $\begin{array}{l}\text { SMPS }(9-900 \mathrm{~nm}) \\
\text { AIS }(0.8-42 \mathrm{~nm})\end{array}$ \\
\hline Man et al. (2015) & $\begin{array}{l}\text { Suburban coastal site, } \\
\text { Hong Kong }\end{array}$ & $12 / 112$ days $(11 \%)$ & $5 / 112$ days $(4 \%)$ & FMPS $(5.6-560 \mathrm{~nm})$ \\
\hline Mazon et al. (2016) & $\begin{array}{l}\text { SMEAR II, boreal forest, } \\
\text { Hyytiala, Finland }\end{array}$ & & $\begin{array}{l}\text { Using neg ions: } \\
\text { 1324/4015 days }(34 \%) \\
\text { Using pos ions: } \\
1172 / 4015 \text { days }(30 \%)\end{array}$ & BSMA (0.8-8 nm) \\
\hline Salimi et al. (2017) & $\begin{array}{l}25 \text { sites across Brisbane } \\
\text { (characterised by urban } \\
\text { environment) }\end{array}$ & $146 / 285$ days $(51 \%)$ & $73 / 285$ days $(26 \%)$ & SMPS (9-414 nm) \\
\hline Kammer et al. (2017) & Landes forest, France & $2 / 16$ days $(12.5 \%)$ & $6 / 16$ days $(37.5 \%)$ & SMPS (10-478 nm) \\
\hline
\end{tabular}

the type and intensity of the sources, concentration of preexisting aerosols, origin of air masses, photo-chemical processes and meteorological parameters such as intensity of solar radiation, temperature, relative humidity, wind direction and wind speed (Birmili and Wiedensohler, 2000; Kulmala et al., 2004, 2013). Pre-existing aerosols act as sinks to condensable gases that are present in the atmosphere. This leads to a reduction in their vapour pressure and inhibits homogeneous nucleation.

Oxides of nitrogen and volatile organic compounds are readily produced in urban environments from sources such as motor vehicles and industrial facilities (Seinfeld and Pandis, 2006; Harrison, 2007). These gases react with ozone in the presence of sunlight to produce $\mathrm{OH}$ radicals that can oxidise gaseous precursors such as sulphur dioxide and nitric oxide, converting them into the condensable species sulfuric acid and nitric acid, respectively. These photochemical reactions are more likely to occur during the day time on sunny days with high intensity of solar radiation, which is when we would expect to observe more NPF events.

Numerous studies in many different environments have conclusively shown that the large majority of NPF occur during the day time (Seinfeld and Pandis, 2006; Suni et al., 2008; Man et al., 2015; Pushpawela et al., 2018). Very few stud- ies have reported the occurrence of NPF during the night time and these have mostly been in forest environments and coastal sites. Table 1 gives a summary of studies in chronological order, that have reported observations and frequencies of occurrence of night time NPF events, together with the respective frequencies of occurrence of day time NPF events and the instrumentation that was used. We see that, at a given location, NPF events were generally more likely to occur during the day time than during the night. The sole exception is the short study of 16 days by Kammer et al. (2017). Night time events were reported on between 4 and $37 \%$ of the days observed. They were more likely to be observed at forest locations (16 to $37 \%$ ), while the two studies conducted at coastal locations showed significantly lower values of 4 and $11 \%$. In a previous study carried out in and around Brisbane with an SMPS, Salimi et al. (2017) reported NPF events on around 1 in every 4 nights. They also reported NPF on every second day which is significantly higher than any of the values found in Brisbane (Guo et al., 2008; Cheung et al., 2011; Crilley et al., 2014; Jayaratne et al., 2016; Pushpawela et al., 2018).

In the present study, we collected data of charged and uncharged particle concentrations in the urban environment of Brisbane using a neutral cluster and air ion spectrometer 
(NAIS) on close to five hundred days. The NAIS can provide more accurate information on NPF than the SMPS, because of its ability to measure particles down to $2 \mathrm{~nm}$ in size, which is very close to the size at which the initial steps of nucleation and formation of particles occur (Manninen et al., 2011, 2016). The results were compared with that obtained simultaneously with an SMPS with a minimum detectable size of $9 \mathrm{~nm}$. The SMPS data were also used to determine the growth rates of particles. The observations by the NAIS and SMPS were used to differentiate between (a) local NPF events followed by particle growth and (b) growth events in the absence of NPF events - two phenomena that are not always concurrent and often misidentified when only one instrument is used.

\section{Methods}

\subsection{Monitoring site}

The instruments were housed in a sixth-floor laboratory in a building at the Gardens Point campus of the Queensland University of Technology in Brisbane, Australia. The site is situated at the edge of the Brisbane Central Business District bordered by the City Botanical Gardens and the Brisbane River, approximately $100 \mathrm{~m}$ away from a busy motorway carrying about 120000 vehicles per day and is representative of a typical urban environment in Australia. The measurements were carried out during the 3 calendar years 2012, 2015 and 2017, yielding 485 complete days of data.

The pollutants at this site were mainly from motor vehicle exhaust emissions. Depending on the wind direction, emissions may also be received from the Port of Brisbane and two oil refineries in its vicinity as well as from Brisbane Airport, all located about $20 \mathrm{~km}$ to the north-east of the monitoring site.

Meteorological data such as temperature, relative humidity, solar radiation, rainfall, wind direction and wind speed as well as air quality data such as sulphur dioxide $\left(\mathrm{SO}_{2}\right)$, ozone $\left(\mathrm{O}_{3}\right), \mathrm{PM}_{10}, \mathrm{PM}_{2.5}$ and atmospheric visibility were obtained from the Department of Environmental and Heritage Protection, Queensland, at their in situ site at the Queensland University of Technology and two other sites within a distance of $1.5 \mathrm{~km}$ from the University.

\subsection{Description of the instruments}

The NAIS, manufactured by Airel Ltd, Estonia (Manninen et al., 2016), detects the mobility distribution of charged clusters and particles of both polarities in the electrical mobility range from 3.2 to $0.0013 \mathrm{~cm}^{2} \mathrm{~V}^{-1} \mathrm{~s}^{-1}$. It also measures the size distribution of total particles in the size range from 2.0 to $42 \mathrm{~nm}$. The instrument has a high-resolution time down to $1 \mathrm{~s}$ and consists of two cylindrical electrical mobility analysers, one for each polarity. It operates in four modes: ion mode; particle mode; alternate charging mode and offset mode. In the ion mode, the NAIS measures naturally charged particles without any modification. In the particle mode, it uses a corona needle to charge the particles. This leads to an inherent problem where the very small particles cannot be distinguished from the corona ions (Manninen et al., 2016). For this reason, we have restricted the lower detection limit in the particle mode to $2 \mathrm{~nm}$. The alternate charging mode is similar to the particle mode, but it electrically neutralises the sampled particles and improves the performance of the instrument. In the offset mode, the NAIS measures zero signals, noise levels and parasitic currents. The measurement process of the instrument is fully automated. The measurement cycle of the NAIS varies from 2 to $5 \mathrm{~min}$. A more detailed discussion of its design and principles is given in Manninen et al. (2011) and Mirme and Mirme (2013). In this study, we set the measurement cycle to $2 \mathrm{~min}$ ion mode, 2 min particle mode, and 1 min offset mode.

An SMPS, consisting of a TSI model 3071 differential mobility analyser and a TSI model 3782 condensation particle counter, was used to measure the particle size distribution in the range from 9 to $415 \mathrm{~nm}$.

\subsection{Data Analysis}

\subsubsection{Classification of new particle formation (NPF) events}

We identified NPF events using the rate of change of total particle concentration, $\mathrm{d} N / \mathrm{d} t$, where $N$ is the number of particles in the size range $2.0-10.0 \mathrm{~nm}$ and using the classification described by Zhang et al. (2004). Events with $N>10000 \mathrm{~cm}^{-3}$ for at least $1 \mathrm{~h}$ and $\mathrm{d} N / \mathrm{d} t>10000 \mathrm{~cm}^{-3} \mathrm{~h}^{-1}$ were defined as "strong" NPF events. Events with $5000<N<10000 \mathrm{~cm}^{-3}$ for at least $1 \mathrm{~h}$ and $5000<\mathrm{d} N / \mathrm{d} t<10000 \mathrm{~cm}^{-3} \mathrm{~h}^{-1}$ were classified as "weak" NPF events. All of these events started in the nucleation mode size range and prevailed over a time span of more than $1 \mathrm{~h}$, generally exhibiting a "banana" shape in the timeseries contour plot of particle number concentration (PNC), indicating particle formation and subsequent growth. A $24 \mathrm{~h}$ day that included at least one NPF event was labelled as an "NPF Day". A day on which there were no NPF events was labelled as a "Non-event Day".

Every NPF event was characterised by a sharp increase of the PNC in the intermediate size range from 2.0 to $7.0 \mathrm{~nm}$. This observation has been used to determine the starting time of an NPF event (Leino et al., 2016). Similarly, in the present study, the starting time of a strong NPF event was determined by noting the time of first occurrence of $\mathrm{d} N / \mathrm{d} t>10000 \mathrm{~cm}^{-3} \mathrm{~h}^{-1}$. The starting time of a weak NPF event was determined by noting the time of first occurrence of $\mathrm{d} N / \mathrm{d} t>5000 \mathrm{~cm}^{-3} \mathrm{~h}^{-1} . N$ is the number of particles in the size range $2.0-10 \mathrm{~nm}$.

NPF events that started between sunrise and sunset were categorised as "day time" NPF. NPF events that started be- 
tween sunset and sunrise were categorised as "night time" NPF.

\subsubsection{Classification of growth events}

The data from the NAIS showed that growth events were not always preceded by an NPF event. Growth events that did not follow an NPF appeared as a "floating banana" shape in the PNC contour plots. These events were identified using the rate of change in the diameter $\left(d_{\mathrm{p}}\right)$ of particle, $d d_{\mathrm{P}} / \mathrm{d} t$. Events with $d d_{\mathrm{p}} / \mathrm{d} t>1 \mathrm{~nm} \mathrm{~h}^{-1}$ were classified as "growth" events. In the NAIS data, these events showed an enhancement of PNC in the size range above $7 \mathrm{~nm}$. Further, in these events, unlike in NPF events, the sharp increase in PNC in the size range between 2 and $7 \mathrm{~nm}$ was absent. In this way, growth events could be clearly distinguished from NPF events. In fact, unless they were preceded by an NPF event, most growth events showed very few particles in the size range below $10 \mathrm{~nm}$. We also observed "vertical band" shapes which were due to the sudden appearance of high concentrations of particles in all sizes. These were neither NPF nor growth events and characterised the influx of already formed particles from further locations to the monitoring site, and were ignored in the analysis.

\subsubsection{Calculation of particles growth rate}

The growth rate (GR) of particles is defined as

$\mathrm{GR}=\frac{d d_{\mathrm{p}}}{\mathrm{d} t}=\frac{d_{\mathrm{p} 2}-d_{\mathrm{p} 1}}{t_{2}-t_{1}}$,

where $d_{\mathrm{p}_{2}}$ and $d_{\mathrm{p}_{1}}$ are the diameters of particles at times $t_{2}$ and $t_{1}$. This was calculated by the maximum concentration method described in Kulmala et al. (2012). The unit of the GR is nanometres per hour. During an NPF or a growth event, the number concentration of small particles increases, showing a peak in the particle size distribution. When the particles grow in size, this peak shifts towards larger sizes. In order to derive the maximum particle concentration, we plotted the time series of the PNC in different size ranges. We estimated the GR from the slope of the best-fitted line on the graph of mid-point diameter of particles versus the time of maximum concentration (Dos Santos et al., 2015; Pierce et al., 2014).

\subsubsection{Statistically significant differences}

Statistical significance of the difference between two parameters were calculated using the Student's $t$ test.

\section{Results and discussion}

\subsection{Observation of NPF during study period}

The study yielded complete $24 \mathrm{~h}$ data on a total of 485 days. The instrument was unavailable on some days, as it was required for other projects or was being serviced or cleaned.
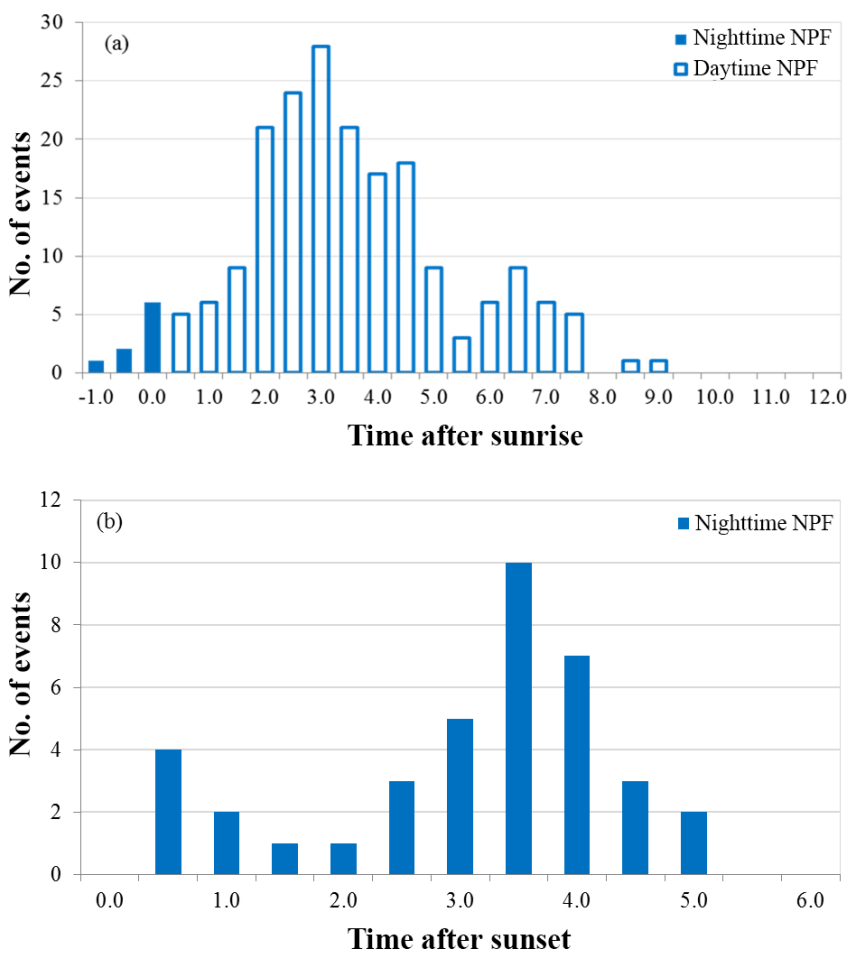

Figure 1. Distribution of start times of day time NPF events as a function of time after sunrise (a) night time NPF events as a function of time after sunset (b). In panel (a) the three bars on the extreme left correspond to times before sunrise.

In addition, a few days were "lost" due to missing data owing to power failures or instrument malfunction. A summary of the observational periods, together with the corresponding number of days on which $24 \mathrm{~h}$ data were available and NPF events were observed, is shown in Table 2. Columns 3 to 8 represent the number of day time, night time and total NPF classified into strong and weak events according to the method described in Sect. 2.3.1. The last three columns give a summary of all NPF events.

Altogether, 236 NPF events (strong and weak) were observed on 213 of the 485 days on which we were able to obtain data. Out of this, strong NPF events were observed on 177 days, giving an occurrence rate of $37 \%$. This is only slightly less than the rate of $41 \%$ found by Pushpawela et al. (2018) using the NAIS in Brisbane over the single calendar year 2012. In the two other studies using the NAIS in Brisbane, Crilley et al. (2014) and Jayaratne et al. (2016) reported higher values of 56 and $45 \%$, respectively. However, both of these previous studies used a slightly different criteria to identify NPF events, that is they excluded the requirement of $N>10000 \mathrm{~cm}^{-3}$ for a period of at least $1 \mathrm{~h}$. The Crilley et al. (2014) study was also conducted over a much shorter period of 36 days only. Table 2 also shows that, although "strong" day time NPF events were observed on 159 days (33\%), "strong" night time NPFs were relatively 
Table 2. Summary of the day time and night time NPF events.

\begin{tabular}{llllllllllll}
\hline & & \multicolumn{3}{c}{ Strong NPF events } & \multicolumn{2}{c}{ Weak NPF events } & \multicolumn{2}{c}{ Total NPF events } \\
\cline { 3 - 11 } Year & $\begin{array}{l}\text { Total data } \\
\text { available days }\end{array}$ & $\begin{array}{l}\text { Day } \\
\text { time }\end{array}$ & $\begin{array}{l}\text { Night } \\
\text { time }\end{array}$ & Total & $\begin{array}{l}\text { Day } \\
\text { time }\end{array}$ & $\begin{array}{l}\text { Night } \\
\text { time }\end{array}$ & Total & $\begin{array}{l}\text { Day } \\
\text { time }\end{array}$ & $\begin{array}{l}\text { Night } \\
\text { time }\end{array}$ & Total \\
\hline 2012 & 253 & 97 & 7 & 104 & 9 & 9 & 18 & 106 & 16 & 122 \\
2015 & 65 & 18 & 4 & 22 & 5 & 7 & 12 & 23 & 11 & 34 \\
2017 & 167 & 44 & 7 & 51 & 16 & 13 & 29 & 60 & 20 & 80 \\
\hline Total events & & 159 & 18 & 177 & 30 & 29 & 59 & 189 & 47 & 236 \\
Total days & 485 & 159 & 18 & 177 & 30 & 29 & 59 & 181 & 47 & 213 \\
Occurrence rate (\%) & & 33 & 4 & 37 & 6 & 6 & 12 & 37 & 10 & 44 \\
\hline
\end{tabular}

scarce, occurring on just 18 days (4\%). Further, "weak" NPF events were observed on 59 days (12\%) and these were almost equally distributed between night and day times. Taking into account all strong and weak NPF, day time NPF occurred on $37 \%$ of the days while night time NPF occurred on only $10 \%$. In Table 2 , it should be noted that a given day may sometimes have both a day time and a night time event. There were 23 such days. In addition, there were 8 days that had two day time events and no instances of two events during the same night. There have been three previous studies that have used an SMPS to study NPF in Brisbane. Together with the occurrence rates in parentheses, these were Guo et al. (2008) (35\%), Cheung et al. (2011) (26\%) and Salimi et al. (2017) $(77 \%)$.

\subsection{Diurnal variation}

Figure 1a and $\mathrm{b}$ show the summary of starting times of all NPF events during the day time and night time, respectively, estimated by using the method described in Sect. 2.3.1. The histograms show the number of events observed in each $30 \mathrm{~min}$ period after sunrise and sunset, respectively. The times indicated on the $x$ axis refer to the end of each $30 \mathrm{~min}$ period. In Fig. 1a, the three bars at the extreme left correspond to times before sunrise. We have classified these as night time events. These figures both show that most NPF events $(71 \%)$ began during the morning, with a high likelihood of occurrence between 2 and $4 \mathrm{~h}$ after sunrise, corresponding to between approximately 08:00 and 10:00 LT. In particular, 90 out of 236 events occurred during this $2 \mathrm{~h}$ period. This is likely to be a result of several factors such as the higher concentration of precursor gases from motor vehicles during the morning rush hour and the onset of solar radiation. However, no NPF were observed during the evening rush hour period around 16:00-18:00 LT. During this time, the air temperatures are still relatively high and, although the gaseous precursors are being produced, the vapour pressures may not be sufficiently high to produce secondary particles. The starting times of night time NPF events also showed a distinct trend with a peak likelihood between 3 and $4 \mathrm{~h}$ after sunset, corresponding to approximately 20:00 and 21:00 LT.
By this time of the day, the temperatures have generally fallen sufficiently for vapour pressures to increase. No night time events were observed at all during the second half of the night, between 23:00 and 04:00 LT. Although the temperatures are low during this time, there is minimum production of precursor gases.

\subsection{Effect of atmospheric parameters}

A summary of the mean and range of various meteorological and air quality parameters during NPF and non-event days is shown in Table 3 . The mean solar radiation intensity on NPF days were significantly higher compared to the other days with mean values of 505 and $397 \mathrm{~W} \mathrm{~m}^{-2}$, respectively. Conversely, the mean relative humidity on NPF days was significantly less than on other days with values of 54 and $66 \%$, respectively. The mean relative humidity on NPF days were 59 and $52 \%$ during winter and summer months. Therefore, NPF events were more likely to occur on days with low relative humidity and high solar radiation. Similar observations have been reported from several other urban sites such as Melpitz, Germany (Birmili and Wiedensohler, 2000), San Pietro Capofiume, Italy (Hamed et al., 2007) and Pune, India (Kanawade et al., 2014).

The wind direction on NPF days was mainly from the south to southwest directions, with a mean wind speed of around $1.4 \mathrm{~m} \mathrm{~s}^{-1}$. The mean air temperature was 17 and $24^{\circ} \mathrm{C}$ on NPF days during winter and summer months. We did not detect any clear differences in wind direction, wind speed and air temperature between NPF days and the other days. In general, most of the NPF events occurred on days when there was no rainfall observed. However, a clear dependence was found between NPF occurrence and atmospheric visibility. The visibility was expressed through the particle back scatter coefficient (BSP) in units of $\mathrm{Mm}^{-1}$. These two parameters are inversely proportional to each other. The BSP observed at 08:00 LT on NPF days was significantly lower on NPF days than on other days, with mean values of 18 and $31 \mathrm{Mm}^{-1}$, respectively. A good discussion about the relationship between the occurrence of NPF in Brisbane and the values of BSP may be found in Jayaratne et al. (2015). 
Table 3. The mean and the range of meteorology and gas phase parameters on NPF and non-event days.

\begin{tabular}{|c|c|c|c|c|c|c|}
\hline \multirow[t]{2}{*}{ Parameter } & \multicolumn{2}{|c|}{ Winter months } & \multicolumn{2}{|c|}{ Summer months } & \multirow[t]{2}{*}{ NPF days } & \multirow{2}{*}{$\begin{array}{l}\text { Non-event } \\
\text { days }\end{array}$} \\
\hline & NPF days & $\begin{array}{l}\text { Non-event } \\
\text { days }\end{array}$ & NPF days & $\begin{array}{l}\text { Non-event } \\
\text { days }\end{array}$ & & \\
\hline \multicolumn{7}{|l|}{ Meteorology } \\
\hline Solar radiation $\left(\mathrm{W} \mathrm{m}^{-2}\right)$ & $346(230-490)$ & $316(95-476)$ & $600(202-818)$ & $476(68-818)$ & $505(202-818)$ & $397(68-818)$ \\
\hline Temperature $\left({ }^{\circ} \mathrm{C}\right)$ & $17(12-19)$ & $16(12-25)$ & $24(18-29)$ & $24(19-32)$ & $21(12-29)$ & $20(12-32)$ \\
\hline Relative humidity (\%) & $59(31-73)$ & $70(27-90)$ & $52(23-73)$ & $63(25-86)$ & $54(23-73)$ & $66(25-90)$ \\
\hline Wind direction $\left(^{\circ}\right)$ & $215(\mathrm{~S}-\mathrm{SW})$ & $203(\mathrm{~S}-\mathrm{SW})$ & $197(\mathrm{~S}-\mathrm{SW})$ & $177(\mathrm{~S}-\mathrm{SW})$ & $205(\mathrm{~S}-\mathrm{SW})$ & $200(\mathrm{~S}-\mathrm{SW})$ \\
\hline Wind speed $\left(\mathrm{m} \mathrm{s}^{-1}\right)$ & $1.07(0.3-3.1)$ & $1.17(0.3-3.6)$ & $1.60(0.3-4.7)$ & $2.25(0.3-5.8)$ & $1.40(0.3-4.7)$ & $1.72(0.3-5.8)$ \\
\hline \multicolumn{7}{|l|}{ Gas phase } \\
\hline Visibility $\left(\mathrm{Mm}^{-1}\right)$ & $15(6-42)$ & $34(2-112)$ & $19(7-41)$ & $29(6-114)$ & $18(6-42)$ & $31(2-114)$ \\
\hline Ozone (ppb) & $12(1-29)$ & $10(2-26)$ & $20(1-32)$ & $19(3-35)$ & $17(1-32)$ & $15(2-35)$ \\
\hline $\mathrm{SO}_{2}(\mathrm{ppb})$ & $7(6-10)$ & $6(1-9)$ & $5(1-14)$ & $3(1-9)$ & $6(1-14)$ & $5(1-9)$ \\
\hline
\end{tabular}

(a)

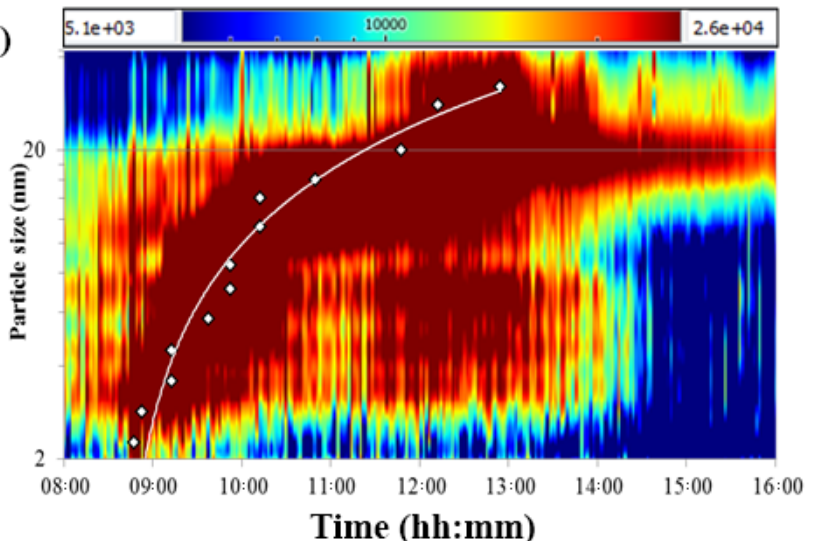

(c)

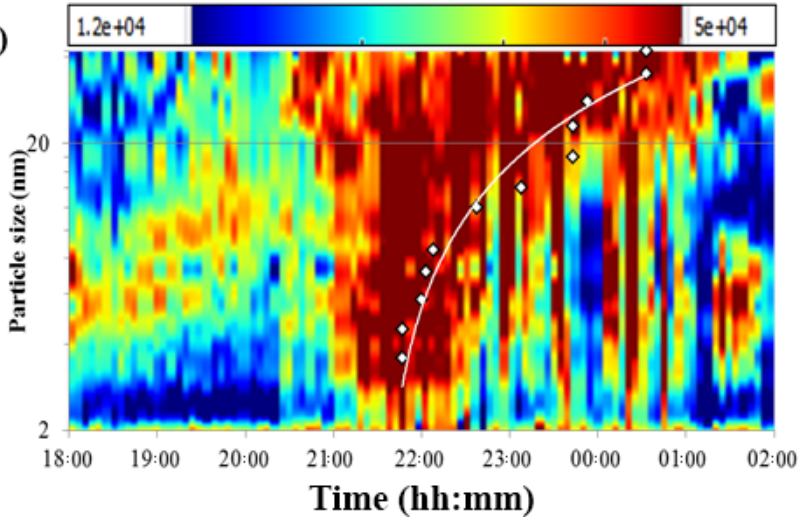

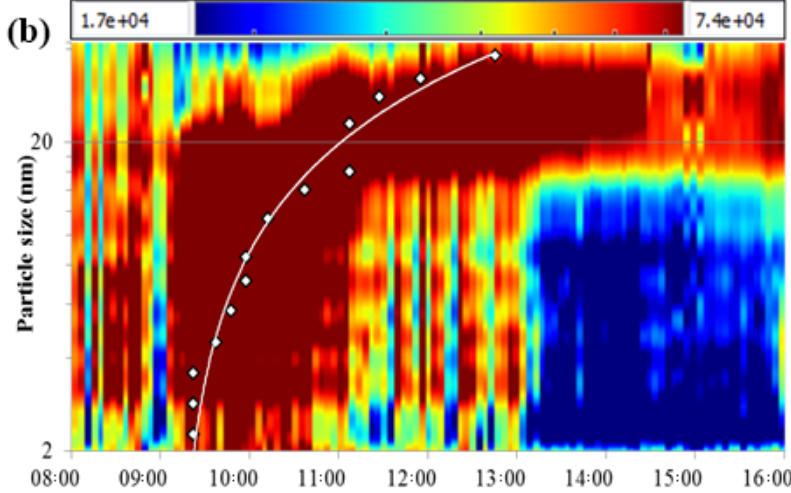

Time (hh:mm)

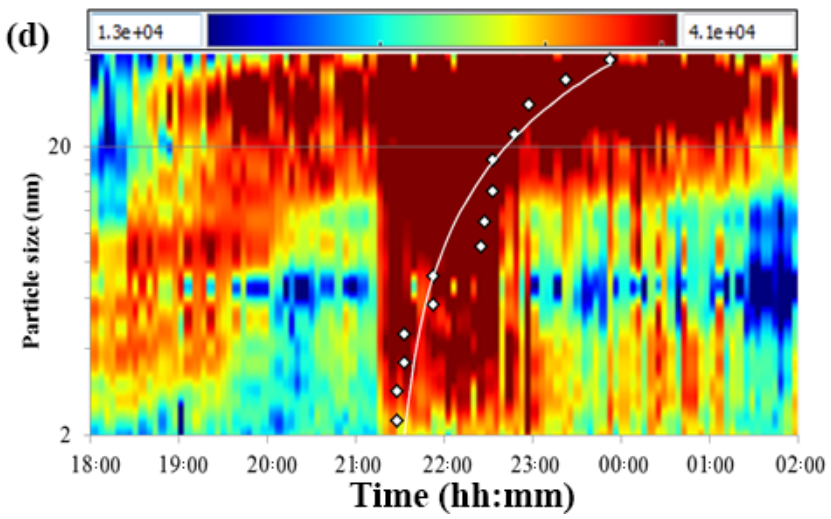

Figure 2. NAIS spectrograms of the day time NPF events $(\mathbf{a}, \mathbf{b})$ and night time NPF (c,d). The colour contour represents the PNC and the markers represent the times at which the PNC reached its maximum value at each particle size. The unit of PNC is per cubic centimetre.

This study also found that, no NPF events occurred on days when the mean $\mathrm{PM}_{2.5}$ exceeded $20 \mu \mathrm{g} \mathrm{m}^{-3}$ in Brisbane.

The presence of high concentration of $\mathrm{O}_{3}$ under high solar radiation increases the production of $\mathrm{OH}$ radicals, and the presence of high concentration of both $\mathrm{SO}_{2}$ and $\mathrm{OH}$ radicals give rise to increased production of $\mathrm{H}_{2} \mathrm{SO}_{4}$ leading to NPF (Seinfeld and Pandis, 2006; Lee et al., 2008). Therefore, we would expect $\mathrm{SO}_{2}$ and $\mathrm{O}_{3}$ concentration levels to be higher on NPF days than on non-event days. However, we observed 
only a marginal increase of $\mathrm{SO}_{2}$ and $\mathrm{O}_{3}$ concentrations on NPF days (Table 3).

\subsection{Day time and night time NPF events}

The two upper panels in Fig. 2 show the NAIS spectrograms obtained between 08:00 and 16:00 LT on 19 August 2017 and 31 July 2015, respectively. On 19 August, a strong NPF event began in the morning at around 09:00 LT and lasted for 4$5 \mathrm{~h}$. Here, the total PNC increased from about $30000 \mathrm{~cm}^{-3}$ at 09:00 LT to just over $90000 \mathrm{~cm}^{-3}$ at 11:00 LT, giving a particle formation rate of $30000 \mathrm{~cm}^{-3} \mathrm{~h}^{-1}$. Thereafter, particles continued to grow in size for several hours. The PNC decreased gradually in the afternoon. The particles showed a relatively high growth rate of about $7 \mathrm{~nm} \mathrm{~h}^{-1}$ in the size range $2-42 \mathrm{~nm}$.

The two lower panels in Fig. 2 show NAIS spectrograms obtained during the night, between 18:00 and 02:00 LT on 20 August 2015 and 5 September 2015, respectively. On 20 August, a strong NPF event began in the night at around 21:30 LT and lasted for 2-3 h. The particles also showed a relatively high growth rate of about $11 \mathrm{~nm} \mathrm{~h}^{-1}$ in the size range $2-42 \mathrm{~nm}$.

We did not observe a significant difference in growth rates of particles between day time and night time NPF events. The growth rate of particles in the size range $2-42 \mathrm{~nm}$ during all NPF events, calculated from Eq. (1), varied between 4 and $22 \mathrm{~nm} \mathrm{~h}^{-1}$ with a mean and standard deviation of $(12.1 \pm 6.5) \mathrm{nm} \mathrm{h}^{-1}$. These growth rates were comparable to the values reported at two other urban locations; Atlanta, USA (3-20 $\mathrm{nm} \mathrm{h}^{-1}$ ) (Stolzenburg et al., 2005) and Budapest, Hungary (2-13 $\mathrm{nm} \mathrm{h}^{-1}$ ) (Salma et al., 2011). However, the mean values of growth rates obtained by previous studies in Brisbane were significantly lower than the value reported by this study. For example, Cheung et al. (2011) and Salimi et al. (2017) reported growth rates of 4.6 and $2.4 \mathrm{~nm} \mathrm{~h}^{-1}$, respectively. Both these studies were carried out using an SMPS with a lower detection size of about $10 \mathrm{~nm}$.

Typically, the particle growth rates were high during the first few hours and then decreased to a few nanometres per hour within 3-4h after nucleation. Several studies have reported that the growth rate of particles in the size range $7-$ $20 \mathrm{~nm}$ was greater than that in the smaller size range $3-7 \mathrm{~nm}$ (Manninen et al., 2010; Gagné et al., 2011; Yli-Juuti et al., 2009; Backman et al., 2012). Manninen et al. (2010) studied NPF events at 12 European sites and found that 9 out of the 12 sites showed this trend while at 3 sites the growth rate was greater in the smaller size range. They suggested that this size dependence was due to different condensing vapours participating in the growth of different sized particles depending on their saturation vapour pressures. For example, it is well known that sulfuric acid plays a dominant role in nucleation and the initial growth of particles during NPF while organics dominate the growth at larger sizes of 10$30 \mathrm{~nm}$ (Yli-Juuti et al., 2011; Manninen et al., 2009; Smith
Table 4. Summary of the growth events, which did not follow the NPF events, obtained using the NAIS data.

\begin{tabular}{lllll}
\hline & & \multicolumn{3}{c}{ Growth events } \\
\cline { 3 - 5 } Year & $\begin{array}{l}\text { Total data } \\
\text { available days }\end{array}$ & $\begin{array}{l}\text { Day } \\
\text { time }\end{array}$ & $\begin{array}{l}\text { Night } \\
\text { time }\end{array}$ & Total \\
\hline 2012 & 253 & 24 & 59 & 83 \\
2015 & 65 & 4 & 21 & 25 \\
2017 & 167 & 26 & 55 & 81 \\
\hline Total events & & 54 & 135 & 189 \\
Total days & 485 & 54 & 135 & 179 \\
Occurrence & & 11 & 28 & 37 \\
rate $(\%)$ & & & & \\
\hline
\end{tabular}

et al., 2008). Further evidence comes from the observation that the growth rate of the particles in the larger size range of $7-20 \mathrm{~nm}$ is enhanced during the summer when the concentration of biogenic volatile organic compounds in the atmosphere is greater (Yli-Juuti et al., 2011). Our observations of particle growth rates in the different size ranges agree with previous studies that have suggested that the dominant condensable vapour in Brisbane is probably sulfuric acid, with organics playing a secondary role (Crilley et al., 2014).

\subsection{Observations of growth events during the study period}

NPF events are almost always followed by particle growth. However, with the NAIS, we observed several growth events that were not preceded by an NPF event. These events were observed more often at night than during the day. A summary of these events observed by the NAIS, is shown in Table 4. Columns 3 to 5 represent the number of day time, night time and total growth events classified according to the method described in Sect. 2.3.2. Figure 3 shows examples of NAIS spectrograms of such growth events that occurred during the day time (a) and night time (b). Particle growth is again demonstrated by the typical banana shape of the colour contours, with the difference that the lower end of the "banana" does not reach as far as the smallest particle sizes, indicating that there is no NPF. This shape is sometimes referred to as a "floating banana", to differentiate it from the complete "banana" shape of an NPF event. In most of the events, particle growth is observed to continue for several hours. The observed rates of growth varied between 1 and $45 \mathrm{~nm} \mathrm{~h}^{-1}$ with a mean and standard deviation of $(16.8 \pm 11.9) \mathrm{nm} \mathrm{h}^{-1}$ in the size range $8-42 \mathrm{~nm}$. During the 485 days of observation, excluding NPF events, day time growth events were observed on just 54 days $(11 \%)$, whereas night time growth events were observed on 135 days $(28 \%)$. The overall occurrence rate of growth events obtained by the NAIS was $37 \%$. However, it should be noted that particles continued to grow at sizes larger than the upper size detection rate of the NAIS, 

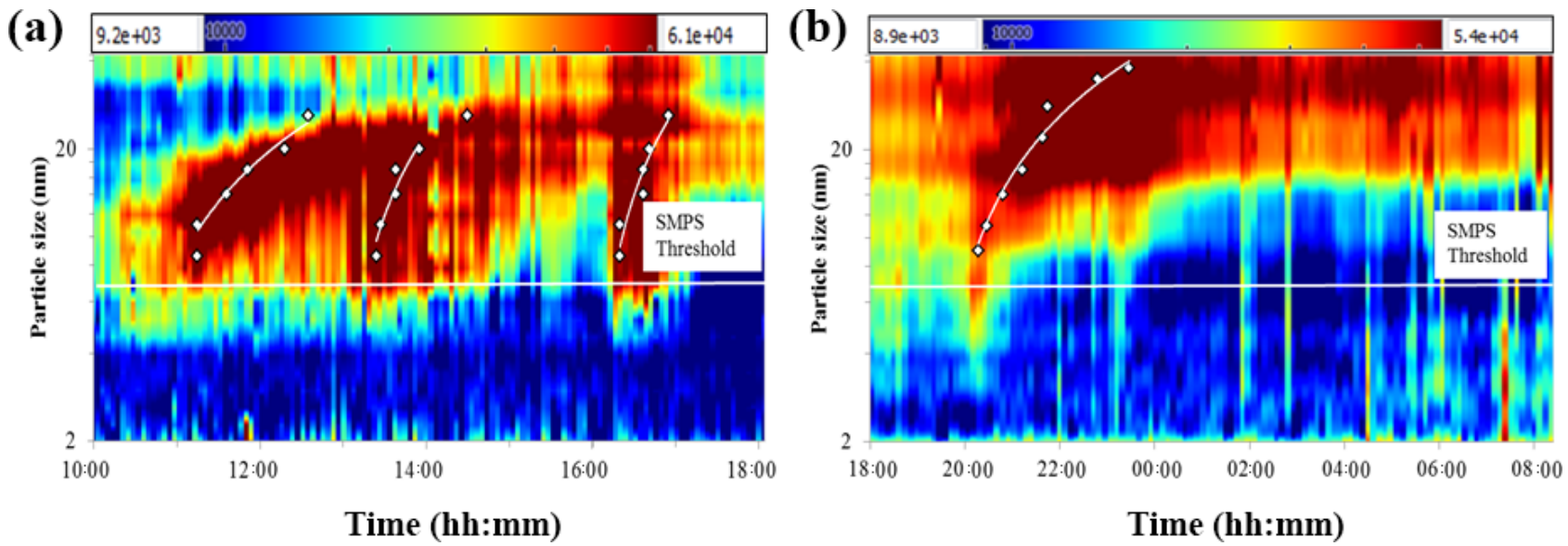

Figure 3. NAIS spectrograms of the growth events that occurred during (a) day time (b) night time. Note the "floating banana" shape, which indicates that these are clearly not NPF events. The SMPS cannot detect particles at sizes below the horizontal white line. The colour contour represents the PNC and the markers represent the times at which the PNC reached its maximum value at each particle size. The unit of PNC is per cubic centimetre.
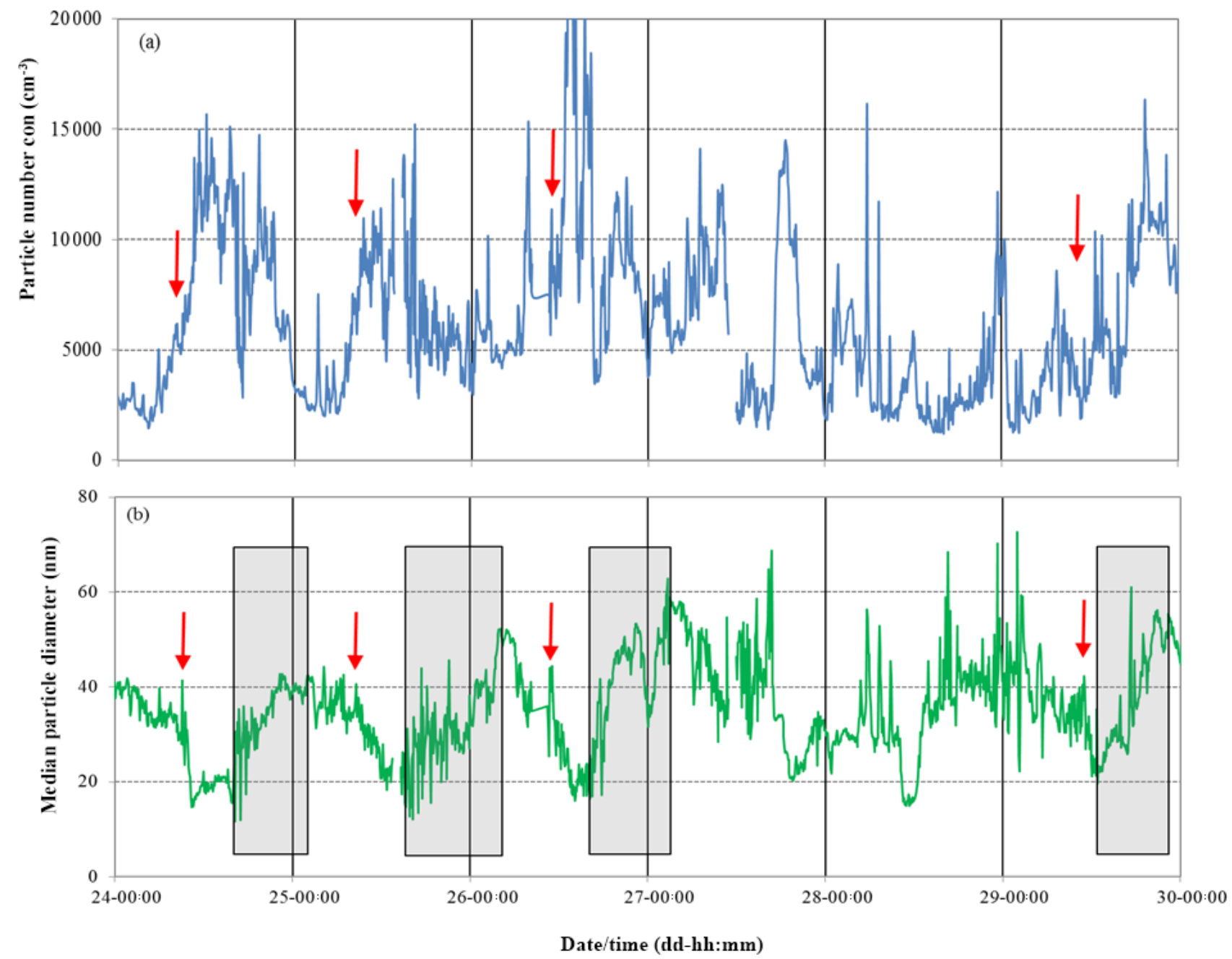

Figure 4. (a) the total PNC and (b) median particle diameter from the SMPS during 24-30 July 2012. Red arrows and gray boxes represent the day time NPF events and the growth events, respectively. 

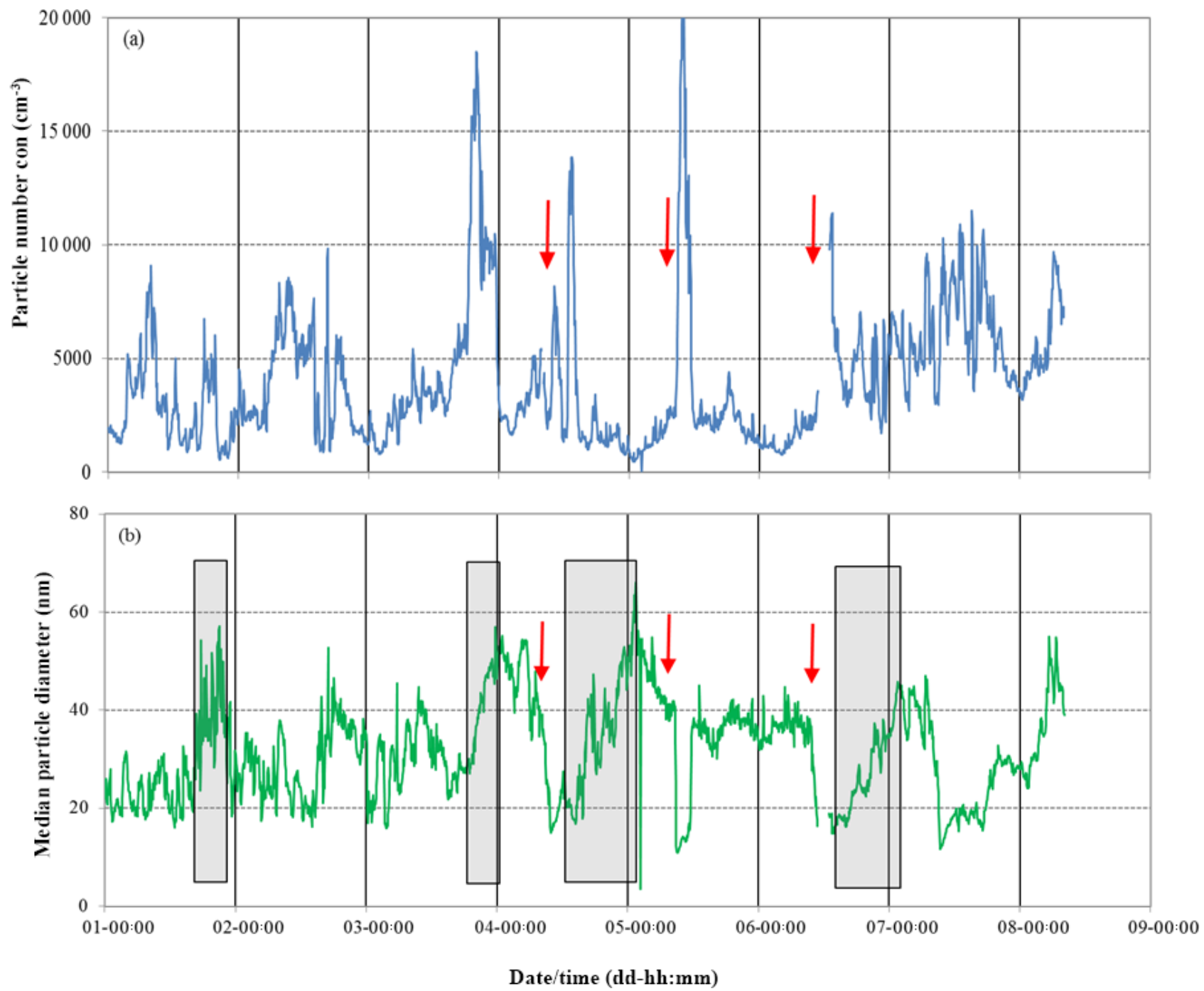

Figure 5. (a) The total PNC and (b) median particle diameter from the SMPS during 1-7 June 2012. Red arrows and gray boxes represent the day time NPF events and the growth events, respectively.

which was $42 \mathrm{~nm}$. Thus, the SMPS was likely to detect many more growth events than the NAIS.

\subsection{Observations of particle growth by SMPS}

Next, we look at the behaviour of total PNC and the median particle diameter of NPF and growth events using the data obtained by the SMPS. Figure 4 shows a period of 6 days, during which there were 3 consecutive day time NPF events that were followed by two non-event days and a day with a day time NPF event. The NPF events are shown by red arrows. In each of these four cases, prior to the inception of the day time NPF, the total PNC was low - about $2500 \mathrm{~cm}^{-3}$. During the NPF event, the total PNC increased from about $5000 \mathrm{~cm}^{-3}$ in the morning to over $15000 \mathrm{~cm}^{-3}$ near midday. Thereafter, the particles started to grow in size up to 20 $30 \mathrm{~nm}$. During and after the late afternoon, although the total
PNC began to decrease, the particles continued to grow in size up to $40-65 \mathrm{~nm}$. All four NPF events continued through this "second phase of particle growth" until the early hours of the next day. The growth rate varied between 2 and $7 \mathrm{~nm} \mathrm{~h}^{-1}$.

Figure 5 shows another example. During this 7 day period, two growth events in the late afternoon were preceded by NPF events. The remaining two growth events did not follow any NPF event. The particles grew up to $40-50 \mathrm{~nm}$. During the measurement period, particle growth events were observed on $65-70 \%$ of the nights.

These observations of continued growth of particles following NPF events is a common phenomenon and has been reported by several other researchers. For example, Man et al. (2015) observed 12 out of 17 NPF events with particle growth from 10 to $40 \mathrm{~nm}$ during the day time at a suburban coastal site in Hong Kong. In addition, they observed three events with second phase of particle growth to $61-97 \mathrm{~nm}$ 

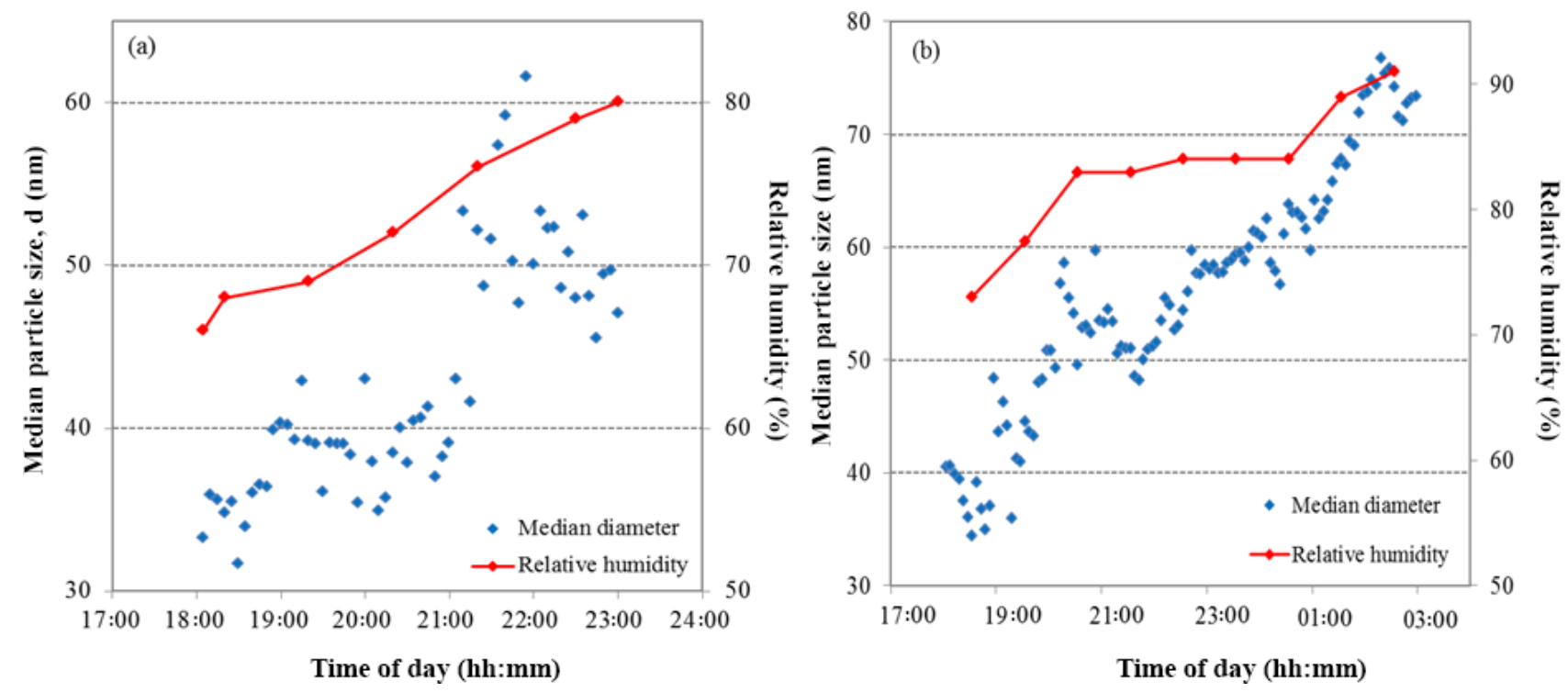

Figure 6. Median particle size and relative humidity as a function of time for growth events on 16 and 20 July 2012 , respectively.

at night time. These three events were preceded by a day time NPF event. Russell et al. (2007) observed nanoparticle growth on 19 out of 48 days (40\%) during the day time and on 5 out of 48 days (10\%) during the night time in Appledore Island, Maine, USA. Subsequently, particle growth continued over several hours with rates varying from 3 to $13 \mathrm{~nm} \mathrm{~h}^{-1}$.

NPF generally occur at high solar radiation, high temperature and low relative humidity. However, growth events were more likely to occur during time periods with low temperature and high relative humidity. We investigated this further by plotting the median particle size and relative humidity as a function of time during growth events (Fig. 6). In general, progression into the night time, after 18:00 LT, was accompanied by a decrease in air temperature, resulting in an increase in relative humidity in the atmosphere.

During the event that occurred on 16 July 2012 the median particle size increased from about 30 to $65 \mathrm{~nm}$ as the relative humidity increased from 65 to $80 \%$ (Fig. 6a). Similarly, during the event that occurred on 20 July 2012 the median particle size increased from about 30 to $75 \mathrm{~nm}$ as the relative humidity increased from 75 to $90 \%$ (Fig. 6b).

It is well-known that relative humidity may favour particle growth in the atmosphere owing to several reasons. For example, atmospheric aerosol particles increase in size with relative humidity due to the uptake of water (Winkler, 1988). In addition, when the relative humidity increases, heterogeneous reactions can take place in the liquid phase of a growing particle while, if there is an accompanying drop in temperature, it would enhance the transport of semivolatile compounds from the gas phase on to the surface of the particles. Water uptake is caused by the deliquescence of soluble salts which form a solution when the solid compound is ex- posed to water vapour at sufficiently high vapour pressure. Several organic materials are also known to absorb water at high humidity which is more generally known as hygroscopicity. Sodium chloride $(\mathrm{NaCl})$ has a deliquescence point of $76 \%$ relative humidity. At this point, a NaCl-bearing particle will deliquesce and become a solution of droplet with a well-defined spherical shape. The particle diameter does not change considerably as the relative humidity is increased from 0 to $74 \%$, beyond which it can increase considerably. Close to the coast, sea salt aerosols constitute a large proportion of the atmospheric particulate mass and $\mathrm{NaCl}$ is a major component. Many of the inorganic substances that readily absorb water, such as sea salt, ammonium salts and nitrates, are present in the Brisbane environment (Harrison, 2007). Therefore, it is not surprising that, in the present study, we observed that particle growth occurred on 7 out of 10 nights with high relative humidity.

\subsection{Probability of growth events being misidentified as NPF events}

In Fig. 3a, the horizontal white line indicates the typical lower size detection threshold of the SMPS that has been used in many locations before; we chose $7 \mathrm{~nm}$ as a typical value in this case. The SMPS does not "see" any particles below this line. It is clear that there is an enhancement of PNC in the size range 7-20 nm around 11:30 LT on this day. The absence of intermediate size particles (between 2 and $7 \mathrm{~nm}$ ) suggests that the $7-20 \mathrm{~nm}$ particles originated on-site by primary emission or were advected to the site from a distant location. The NAIS clearly shows that this was not an NPF event. However, in the absence of information below a particle size of $7 \mathrm{~nm}$, the SMPS data may be easily mis- 
interpreted as an NPF event. The typical "floating banana" shape of the spectrogram contours show that the particles continue to grow between 11:30 LT and about 13:00 LT, and this can be observed by an SMPS. As we have demonstrated, growth events are not always formation events. There are two enhancement events near 13:00 and 15:30 LT. Once again, the NAIS shows that neither of these are NPF events, although based on the SMPS they may be mistakenly identified as such. Figure $3 \mathrm{~b}$ shows another event that can be easily misidentified as an NPF event based on SMPS data alone.

Salimi et al. (2017), using an SMPS with a lower size limit of $9 \mathrm{~nm}$ at 25 sites across Brisbane, reported 219 NPF events out of 285 days of measurements. This occurrence rate of $77 \%$ (67\% of day time and $33 \%$ of night time) is significantly higher than any of the values found previously in Brisbane and at any other location in the world. With the NAIS, it was possible to show that most of these events were growth events and not NPF events. It was not possible to differentiate these two types of events with the SMPS alone as it provides no knowledge of the PNC below $9 \mathrm{~nm}$. With the NAIS, we did not observe nocturnal NPF events on more than 47 of 500 days.

In many NPF events, particle growth ceases after they have grown to a certain size. In the growth event in Fig. 3, the maximum size is about $25 \mathrm{~nm}$. In such cases, the greater part of the "banana" profile is below $7 \mathrm{~nm}$ and, thus, invisible to the SMPS. This could result in the missing of such NPF events. Considering, all the factors above, it is clear that the NAIS has a distinct advantage over the SMPS in correctly identifying NPF events in the atmosphere.

\section{Summary and Conclusions}

We monitored charged and neutral PNCs in the size range 2$42 \mathrm{~nm}$ on nearly 500 days over 3 calendar years in the urban environment of Brisbane, Australia, using a NAIS. The data were used to differentiate between NPF events and growth events with no NPF. Day time NPF events were observed on $37 \%$ of the observational days, with night time events on only $10 \%$ of the days. NPF events were more likely to occur on days with low relative humidity and high solar radiation. $71 \%$ of NPF events occurred during the morning, with the highest probability of occurrence between 2 and $4 \mathrm{~h}$ after sunrise, corresponding to approximately between 08:00 and 10:00 LT. Most of the night time events occurred between 3 and $4 \mathrm{~h}$ after sunset, corresponding to approximately between 20:00 and 21:00 LT. No night time events were observed between 23:00 and 04:00 LT. $28 \%$ of the particle growth events that occurred at night were not preceded by an NPF event. These events were characterised by high growth rates of up to $45 \mathrm{~nm} \mathrm{~h}^{-1}$. The SMPS results showed that particle growth continued at larger sizes from $\sim 40$ to $70 \mathrm{~nm}$ and occurred on $70 \%$ of nights. Maximum relative humidities were over $80 \%$ on most of these nights. These results show that, when par- ticles are monitored by an instrument such as the SMPS that cannot detect them at the very small sizes, particle growth in the atmosphere may be easily misidentified as NPF, leading to an overestimation of the frequency of the latter.

Data availability. All data used in this paper are available upon request from the corresponding author Lidia Morawska (1.morawska@qut.edu.au)

Author contributions. BP co-designed the study, carried out the measurements, processed and analysed the data, interpreted the results, and wrote the paper. RJ co-designed the study, interpreted the results, and wrote the paper. LM assisted with interpreting the results and reviewed the manuscript.

Competing interests. The authors declare that they have no conflict of interest.

Acknowledgements. We are thankful to the Department of Environmental and Heritage Protection, Queensland, for providing some of the meteorological data used in this study.

Edited by: Veli-Matti Kerminen

Reviewed by: three anonymous referees

\section{References}

Backman, J., Rizzo, L. V., Hakala, J., Nieminen, T., Manninen, H. E., Morais, F., Aalto, P. P., Siivola, E., Carbone, S., Hillamo, R., Artaxo, P., Virkkula, A., Petäjä, T., and Kulmala, M.: On the diurnal cycle of urban aerosols, black carbon and the occurrence of new particle formation events in springtime São Paulo, Brazil, Atmos. Chem. Phys., 12, 11733-11751, https://doi.org/10.5194/acp-12-11733-2012, 2012.

Birmili, W. and Wiedensohler, A.: New particle formation in the continental boundary layer: Meteorological and gas phase parameter influence, Geophys. Res. Lett., 27, 3325-3328, 2000.

Cheung, H. C., Morawska, L., and Ristovski, Z. D.: Observation of new particle formation in subtropical urban environment, Atmos. Chem. Phys., 11, 3823-3833, https://doi.org/10.5194/acp11-3823-2011, 2011

Crilley, L. R., Jayaratne, E. R., Ayoko, G. A., Miljevic, B., Ristovski, Z., and Morawska, L.: Observations on the formation, growth and chemical composition of aerosols in an urban environment, Environ. Sci. Technol., 48, 6588-6596, 2014.

Dos Santos, V. N., Herrmann, E., Manninen, H. E., Hussein, T., Hakala, J., Nieminen, T., Aalto, P. P., Merkel, M., Wiedensohler, A., Kulmala, M., Petäjä, T., and Hämeri, K.: Variability of air ion concentrations in urban Paris, Atmos. Chem. Phys., 15, $13717-$ 13737, https://doi.org/10.5194/acp-15-13717-2015, 2015.

Gagné, S., Lehtipalo, K., Manninen, H., Nieminen, T., Schobesberger, S., Franchin, A., Yli-Juuti, T., Boulon, J., Sonntag, A., and Mirme, S.: Intercomparison of air ion spectrometers: an eval- 
uation of results in varying conditions, Atmos. Meas. Tech., 4, 805-822, https://doi.org/10.5194/amt-4-805-2011, 2011.

Guo, H., Ding, A., Morawska, L., He, C., Ayoko, G., Li, Y. S., and Hung, W. T.: Size distribution and new particle formation in subtropical eastern Australia, Environ. Chem., 5, 382-390, 2008.

Hamed, A., Joutsensaari, J., Mikkonen, S., Sogacheva, L., Dal Maso, M., Kulmala, M., Cavalli, F., Fuzzi, S., Facchini, M. C., Decesari, S., Mircea, M., Lehtinen, K. E. J., and Laaksonen, A.: Nucleation and growth of new particles in Po Valley, Italy, Atmos. Chem. Phys., 7, 355-376, https://doi.org/10.5194/acp-7355-2007, 2007.

Harrison, R. M.: Understanding our environment: an introduction to environmental chemistry and pollution, Roy. Soc. Chem., 3rd edition, Cambridge, 2007.

Jayaratne, E. R., Clifford, S., and Morawska, L.: Atmospheric Visibility and $\mathrm{PM}_{10}$ as Indicators of New Particle Formation in an Urban Environment, Environ. Sci. Technol., 49, 12751-12757, https://doi.org/10.1021/acs.est.5b01851, 2015.

Jayaratne, E. R., Pushpawela, B., and Morawska, L.: Temporal evolution of charged and neutral nanoparticle concentrations during atmospheric new particle formation events and its implications for ion-induced nucleation, Front. Environ. Sci. Eng., 10, p. 13, 2016.

Jayaratne, R., Pushpawela, B., He, C., Li, H., Gao, J., Chai, F., and Morawska, L.: Observations of particles at their formation sizes in Beijing, China, Atmos. Chem. Phys., 17, 8825-8835, https://doi.org/10.5194/acp-17-8825-2017, 2017.

Junninen, H., Hulkkonen, M., Riipinen, I., Nieminen, T., Hirsikko, A., Suni, T., Boy, M., Lee, S. H., Vana, M., and Tammet, H.: Observations on nocturnal growth of atmospheric clusters, Tellus B, 60, 365-371, 2008.

Kalivitis, N., Stavroulas, I., Bougiatioti, A., Kouvarakis, G., Gagné, S., Manninen, H. E., Kulmala, M., and Mihalopoulos, N.: Night-time enhanced atmospheric ion concentrations in the marine boundary layer, Atmos. Chem. Phys., 12, 3627-3638, https://doi.org/10.5194/acp-12-3627-2012, 2012.

Kammer, J., Perraudin, E., Flaud, P.-M., Lamaud, E., Bonnefond, J., and Villenave, E.: Observation of nighttime new particle formation over the French Landes forest, Sci. Total Environ., 621, 1084-1092, 2017.

Kanawade, V., Tripathi, S. N., Siingh, D., Gautam, A. S., Srivastava, A. K., Kamra, A. K., Soni, V. K., and Sethi, V.: Observations of new particle formation at two distinct Indian subcontinental urban locations, Atmos. Environ., 96, 370-379, 2014.

Kulmala, M., Vehkamäki, H., Petäjä, T., Dal Maso, M., Lauri, A., Kerminen, V.-M., Birmili, W., and McMurry, P. H.: Formation and growth rates of ultrafine atmospheric particles: a review of observations, J. Aerosol Sci., 35, 143-176, 2004.

Kulmala, M., Petäjä, T., Nieminen, T., Sipilä, M., Manninen, H. E., Lehtipalo, K., Dal Maso, M., Aalto, P. P., Junninen, H., and Paasonen, P.: Measurement of the nucleation of atmospheric aerosol particles, Nat. Protoc., 7, 1651-1667, 2012.

Kulmala, M., Kontkanen, J., Junninen, H., Lehtipalo, K., Manninen, H. E., Nieminen, T., Petäjä, T., Sipilä, M., Schobesberger, S., and Rantala, P.: Direct observations of atmospheric aerosol nucleation, Science, 339, 943-946, 2013.

Lee, S. H., Young, L. H., Benson, D. R., Suni, T., Kulmala, M., Junninen, H., Campos, T. L., Rogers, D. C., and Jensen, J.: Observations of nighttime new particle formation in the troposphere, J. Geophys. Res.-Atmos., 113, D10210, https://doi.org/10.1029/2007JD009351, 2008.

Leino, K., Nieminen, T., Manninen, H. E., Petäjä, T., Kerminen, V.M., and Kulmala, M.: Intermediate ions as a strong indicator of new particle formation bursts in a boreal forest, Boreal Environ. Res., 21, 274-286, 2016.

Man, H., Zhu, Y., Ji, F., Yao, X., Lau, N. T., Li, Y., Lee, B. P., and Chan, C. K.: Comparison of daytime and nighttime new particle growth at the HKUST supersite in Hong Kong, Environ. Sci. Technol., 49, 7170-7178, 2015.

Manninen, H. E., Nieminen, T., Riipinen, I., Yli-Juuti, T., Gagné, S., Asmi, E., Aalto, P. P., Petäjä, T., Kerminen, V.-M., and Kulmala, M.: Charged and total particle formation and growth rates during EUCAARI 2007 campaign in Hyytiälä, Atmos. Chem. Phys., 9, 4077-4089, https://doi.org/10.5194/acp-9-4077-2009, 2009.

Manninen, H., Nieminen, T., Asmi, E., Gagné, S., Häkkinen, S., Lehtipalo, K., Aalto, P., Vana, M., Mirme, A., and Mirme, S.: EUCAARI ion spectrometer measurements at 12 European sites - analysis of new particle formation events, Atmos. Chem. Phys., 10, 7907-7927, https://doi.org/10.5194/acp10-7907-2010, 2010.

Manninen, H. E., Franchin, A., Schobesberger, S., Hirsikko, A., Hakala, J., Skromulis, A., Kangasluoma, J., Ehn, M., Junninen, H., Mirme, A., Mirme, S., Sipilä, M., Petäjä, T., Worsnop, D. R., and Kulmala, M.: Characterisation of corona-generated ions used in a Neutral cluster and Air Ion Spectrometer (NAIS), Atmos. Meas. Tech., 4, 2767-2776, https://doi.org/10.5194/amt-4-27672011, 2011.

Manninen, H. E., Mirme, S., Mirme, A., Petäjä, T., and Kulmala, M.: How to reliably detect molecular clusters and nucleation mode particles with Neutral cluster and Air Ion Spectrometer (NAIS), Atmos. Meas. Tech., 9, 3577-3605, https://doi.org/10.5194/amt-9-3577-2016, 2016.

Mazon, S. B., Kontkanen, J., Manninen, H. E., Nieminen, T., Kerminen, V.-M., and Kulmala, M.: A long-term comparison of nighttime cluster events and daytime ion formation in a boreal forest, Boreal Environ. Res., 21, 242-261, 2016.

Mirme, S. and Mirme, A.: The mathematical principles and design of the NAIS - a spectrometer for the measurement of cluster ion and nanometer aerosol size distributions, Atmos. Meas. Tech., 6, 1061-1071, https://doi.org/10.5194/amt-6-1061-2013, 2013.

Pierce, J. R., Westervelt, D. M., Atwood, S. A., Barnes, E. A., and Leaitch, W. R.: New-particle formation, growth and climaterelevant particle production in Egbert, Canada: analysis from 1 year of size-distribution observations, Atmos. Chem. Phys., 14, 8647-8663, https://doi.org/10.5194/acp-14-8647-2014, 2014.

Pushpawela, B., Jayaratne, R., and Morawska, L.: Temporal distribution and other characteristics of new particle formation events in an urban environment, Environ. Pollut., 233, 552-560, 2018.

Rose, C., Sellegri, K., Asmi, E., Hervo, M., Freney, E., Colomb, A., Junninen, H., Duplissy, J., Sipilä, M., Kontkanen, J., Lehtipalo, K., and Kulmala, M.: Major contribution of neutral clusters to new particle formation at the interface between the boundary layer and the free troposphere, Atmos. Chem. Phys., 15, 34133428, https://doi.org/10.5194/acp-15-3413-2015, 2015.

Russell, L., Mensah, A., Fischer, E., Sive, B., Varner, R., Keene, W., Stutz, J., and Pszenny, A.: Nanoparticle growth following photochemical $\alpha$-and $\beta$-pinene oxidation at Appledore Island during International Consortium for Research on 
Transport and Transformation/Chemistry of Halogens at the Isles of Shoals 2004, J. Geophys. Res.-Atmos., 112, D10S21 https://doi.org/10.1029/2006JD007736, 2007.

Salimi, F., Rahman, Md. M., Clifford, S., Ristovski, Z., and Morawska, L.: Nocturnal new particle formation events in urban environments, Atmos. Chem. Phys., 17, 521-530, https://doi.org/10.5194/acp-17-521-2017, 2017.

Salma, I., Borsós, T., Weidinger, T., Aalto, P., Hussein, T., Dal Maso, M., and Kulmala, M.: Production, growth and properties of ultrafine atmospheric aerosol particles in an urban environment, Atmos. Chem. Phys., 11, 1339-1353, https://doi.org/10.5194/acp-11-1339-2011, 2011.

Seinfeld, J. H. and Pandis, S. N.: Atmospheric chemistry and physics, Hoboken, NJ, Wiley, 2006.

Smith, J., Dunn, M., VanReken, T., Iida, K., Stolzenburg, M., McMurry, P., and Huey, L.: Chemical composition of atmospheric nanoparticles formed from nucleation in Tecamac, Mexico: Evidence for an important role for organic species in nanoparticle growth, Geophys. Res. Lett., 35, L04808, https://doi.org/10.1029/2007GL032523, 2008.

Stolzenburg, M. R., McMurry, P. H., Sakurai, H., Smith, J. N., Mauldin, R. L., Eisele, F. L., and Clement, C. F.: Growth rates of freshly nucleated atmospheric particles in Atlanta, J. Geophys. Res.-Atmos., 110, D22S05, https://doi.org/10.1029/2005JD005935, 2005.

Suni, T., Kulmala, M., Hirsikko, A., Bergman, T., Laakso, L., Aalto, P. P., Leuning, R., Cleugh, H., Zegelin, S., Hughes, D., van Gorsel, E., Kitchen, M., Vana, M., Hõrrak, U., Mirme, S., Mirme, A., Sevanto, S., Twining, J., and Tadros, C.: Formation and characteristics of ions and charged aerosol particles in a native Australian Eucalypt forest, Atmos. Chem. Phys., 8, 129-139, https://doi.org/10.5194/acp-8-129-2008, 2008.
Svenningsson, B., Arneth, A., Hayward, S., Holst, T., Massling, A., Swietlicki, E., Hirsikko, A., Junninen, H., Riipinen, I., and Vana, M.: Aerosol particle formation events and analysis of high growth rates observed above a subarctic wetland-forest mosaic, Tellus B, 60, 353-364, 2008.

Winkler, P.: The growth of atmospheric aerosol particles with relative humidity, Physica Scripta, 37, p. 223, 1988.

Yli-Juuti, T., Riipinen, I., Aalto, P. P., Nieminen, T., Maenhaut, W., Janssens, I. A., Claeys, M., Salma, I., Ocskay, R., and Hoffer, A.: Characteristics of new particle formation events and cluster ions at K-puszta, Hungary, Boreal Environ. Res., 14, 683-698, 2009.

Yli-Juuti, T., Nieminen, T., Hirsikko, A., Aalto, P., Asmi, E., Hõrrak, U., Manninen, H., Patokoski, J., Maso, M. D., and Petäjä, T.: Growth rates of nucleation mode particles in Hyytiälä during 2003-2009: variation with particle size, season, data analysis method and ambient conditions, Atmos. Chem. Phys., 11, 12865-12886, https://doi.org/10.5194/acp-11-12865-2011, 2011.

Zhang, Q., Stanier, C. O., Canagaratna, M. R., Jayne, J. T., Worsnop, D. R., Pandis, S. N., and Jimenez, J. L.: Insights into the chemistry of new particle formation and growth events in Pittsburgh based on aerosol mass spectrometry, Environ. Sci. Technol., 38, 4797-4809, 2004. 